\title{
EFFECTS OF THE POSITION IN A STEM ON THE VARIABILITY OF TRACHEIDS IN SPRUCE (Picea abies /L./ Karst.) WITH THE OCCURRENCE OF REACTION WOOD
}

\author{
V. Gryc, H. Vavrčík
}

Received: January 10, 2010

\begin{abstract}
GRYC, V., VAVRČÍK, H.: Effects of the position in a stem on the variability of tracheids in spruce (Picea abies /L./ Karst.) with the occurrence of reaction wood. Acta univ. agric. et silvic. Mendel. Brun., 2010, LVIII, No. 2, pp. 77-86

The paper is aimed at the field of the microscopic structure of wood dealing with the description of the most important anatomic element in softwood - tracheids in a stem with the occurrence of reaction wood. Significant changes of tracheids were found along the height and radius of a stem. There were statistically significant differences between particular annual rings (variability along the stem radius). The height of a stem was also statistically significant. On the basis of the results obtained 3D models were created (for zones compression wood, opposite wood and site wood; models for radial dimension an early-wood tracheid and late-wood tracheid) depicting changes in transverse dimensions of the spruce tracheid in relation to its position in a stem. Structure of ring with compression wood was studied too. It was observed that the ring with occurrence of compression wood has a following structure: early wood tracheids at the beginning of the growing season, transitional tracheids, compression tracheids and at the end of an annual ring typical late wood tracheids. The rings with compression wood show more tracheids as compared with annual rings from the opposite side.
\end{abstract}

Norway spruce, tracheid, radial dimensions of tracheid, compression wood

Forests are managed to meet a variety of objectives. When wood production is the objective of management, the forester has a number of techniques available for stimulating wood production and ensuring renewal of the forest. Often the focus of management is to maximize the volume of wood produced. It is important, however, to keep in mind that whatever is done to modify the growth rate can also modify the properties of wood being grown. Wood quality characteristics can be inherent to particular species, but are also influenced by tree growing conditions. This connection to tree growth gives forest managers both an opportunity and an obligation to manage judiciously for value on every site be it only through choice of rotation length, species selection, and initial spacing and stocking control on some sites, to fertilization, thinning and pruning on others (Gryc and Horáček, 2004).
When an actively growing softwood stem is tipped from the vertical, it almost immediately begins producing wood on the underside of the leaning stem that is different from normal. Stems tipped as little as several degrees from the vertical may begin producing abnormal cells within several hours of the change in stem orientation. This wood, known as compression wood, is of interest because its properties are considerably different from, and much less desirable than, normal mature wood. The appearance of compression wood differs from that of normal mature wood in respect of anatomical structure, chemical composition, and physical and mechanical properties. This kind of wood is also sometimes formed on the lower edges of branches, playing an important role in controlling branch angle.

The behaviour and properties of wood are the expression of its structure on all levels, viz submicro- 
scopic, microscopic and macroscopic. Thus, wood structure gives unambiguous answers why the wood behaves or behaved in that way. Wood is a complicated non-homogeneous and anisotropic material of organic origin (Kučera, 1973). The anatomical structure of softwood consists only of two types of anatomical elements: tracheids and parenchymatous cells (Plomino et. al, 2001; Panshin and Zeeuw, 1980; Matovič and Gandelová, 1980; Kollmann, 1951; Trendelenburg, 1939).

Within annual rings, it is possible to observe two types of tracheids, early-wood tracheids and latewood tracheids. Early-wood tracheids are formed by cambium at the beginning of the growing season. The tracheids are characterized by thin cell walls and wide lumen their function in wood being conductive. At the end of the growing season, cambium creates so-called late-wood tracheids which are thick-wall showing a narrow lumen. Their function in wood is mechanical (Horáček, 2003; Wagenführ, 1999; Bötsche and Kühn 1988; Timell, 1986; Dewitz, 1969). Dimensions of tracheids within an annual ring decrease from early wood to late wood (Horáček, 2003; Mitschell and Denne, 1997; Wagenführ, 1989; Bötsche and Kühn, 1988; Fengel and Stoll, 1973; Denne, 1973). Dimensions of tracheids also change within the stem radius. Along the stem radius - from the stem pith to cambium - dimensions of tracheids increase. The most marked increment occurs in the region of juvenile wood. In next years, it is possible to observe increase in the value or stagnation. The cell wall thickness shows an inverse trend as compared with the tracheid dimensions which means the gradual increment of the cell wall thickness from spring to late wood. (Gryc and Horáček, 2003; Sarén et al., 2001; Matovič and Gandelová, 1989; Panshin and Zeeuw, 1980; Trendelenburg, 1939).

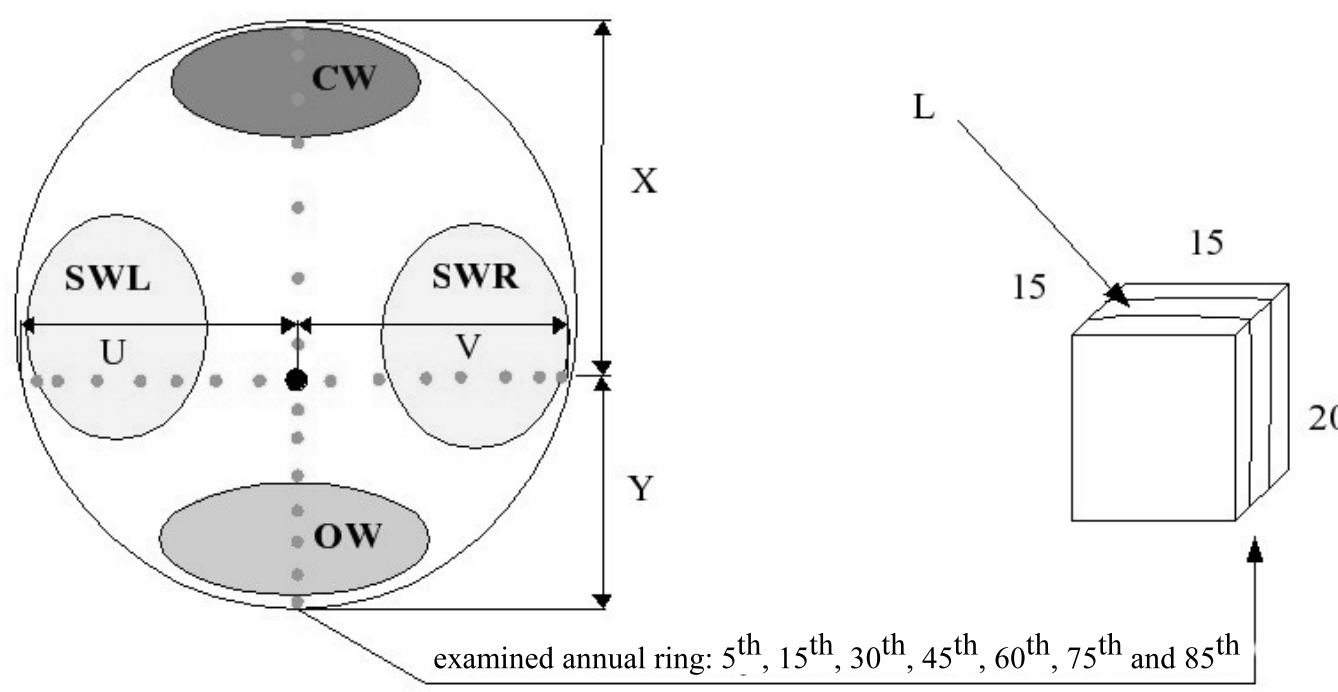

1: Sampling positions, dimensions of samples (mm); X, Y, U, V-directions of measurement, CW-zone of compression wood, OW-opposite zone, SWL a SWR - zones of lateral wood, - - examined annual rings, $L$-examined annual ring
The compression wood is created on the lower part of bent stems and branches. On the microscopic level, compression wood is expressed by the modified structure of tracheids. Tracheids of the normal wood are of tetragonal or hexagonal form on their cross section whereas tracheids of compression wood are of circular form. Thus, there are intercellular spaces between particular tracheids. Also the cell wall structure is modified in compression wood. The cell wall shows a thickened secondary cell wall, $\mathrm{S}_{3}$ layer is missing and a fibril structure demonstrates the marked deviation of fibrils from a vertical axis (Wagenführ, 1999; Mauer and Fengel, 1991; Timell, 1986; Casperson and Zinßer, 1965; Casperson, 1962; Knige, 1958; Rak, 1957, Trendelenburg, 1932). Timell (1986) found that tracheids of compression wood showed a smaller radial diameter as compared with tracheids of normal wood. Onaka (1949) mentions that early-wood tracheids are smaller in compression wood while late-wood tracheids show an inverse trend, ie late-wood tracheids are larger in compression wood.

The paper is aimed at the field of the microscopic structure of wood dealing with the description of the most important anatomic element in softwood tracheids in a stem with the occurrence of reaction wood. The objective of the paper is to describe variability of early-wood and late-wood tracheids within the annual ring, radius and stem height. Another objective is to determine if there is a significant effect on tracheid dimensions between particular zones of a stem (compression zone - CW, opposite zone OW).

\section{MATERIAL AND METHODS}

In the Training Forest Enterprise "Masaryk Forest" Křtiny - Mendel University in Brno, Forest Dis- 
trict Habrůvka (49 $19^{\circ}$ ' 12" N, $16^{\circ} 43^{\prime} 21$ 'E, mean annual temperature $7.5^{\circ} \mathrm{C}$, mean annual precipitation $610 \mathrm{~mm}$ ), one sample tree of Norway spruce (Picea abies (L.) Karst.) was selected where the occurrence of reaction wood was supposed. A tree was selected the stem axis of which was deflected from the direction of gravity. The age of the selected tree was 110 years. The total tree height was $33 \mathrm{~m}$.

Eight discs of $100 \mathrm{~mm}$ in thickness were taken from the tree at a height of $6,8,10,12,15,18,20$ and $22 \mathrm{~m}$. In each of the discs, the direction of measurement was marked: the zone of reaction wood (X), opposite zone (Y) and two lateral zones (U and V), see Fig. 1.

To determine variability of the tracheid transverse dimension in relation to the position in a stem samples of wood were taken in respective zones (CW, OW, SWL and SWR), in the 5th, 15th, 30th, 45th, 60th, 75th and 85th annual rings counted from cambium and heights $(6,8,10,12,15,18,20$ and $22 \mathrm{~m})$. Dimensions of the wood samples were as follows: cross section $15 \times 15 \mathrm{~mm}$ and length $20 \mathrm{~mm}$ (Fig. 1) and permanent slides were prepared (according VAVRČÍK and GRYC 2004).

After setting the permanent preparation, transversal sections were taken by means of a digital camera. The photographs were evaluated by means of the Lucia program. In each of the cross sections, five series of tracheids were measured in a radial direction. Late-wood tracheids (LWT) were defined according to Morkov criterion (1928); the size of the LWT lumen has to be smaller on the cross section than the cell wall double (measured in radial direction). The relative position in an annual ring was calculated according to a formula:

$$
\text { relative position }=\frac{p}{n} \text {, }
$$

where

p .... tracheid order in an annual ring,

$n$.... number of all tracheids in an annual ring.
Values obtained were statistically processed according to the Statistica 6.0 program (descriptive statistics, ANOVA) and Table Curve 3D 4.0 (tracheid variability in relation to its position in a stem).

\section{RESULTS}

Descriptive statistics for transverse dimensions of EWT and LWT in radial direction are given in Table I. Mean values of a tracheid in a transverse direction for particular zones (CW, OW, SWL and SWR) are depicted by means of a box diagram (all measured data were used) - Fig. 2. The diagram shows that the dimension of an early-wood tracheid (EWT) ranges below the limit of $30 \mu \mathrm{m}$ in all zones. The mean transverse dimension of a LWT in a radial direction ranges from 15 to $17 \mu \mathrm{m}$. In zones CW and SWR, the values are roughly on the same level (about $16 \mu \mathrm{m}$ ). The highest mean was found in an EWT in zone SWL $(17 \mu \mathrm{m})$, the lowest mean was found in the opposite zone (OW) with a value of about $15 \mu \mathrm{m}$.

Statistical studies demonstrate that there are statistically significant differences between mean values of the transverse dimension of an EWT in particular zones. These significant differences were found between all zones. In a LWT, statistically significant differences were found between some zones (Table II).

Based on the measured data, models were constructed for particular zones describing the variability of EWT and LWT along the stem radius and height. For models describing the early-wood tracheid variability those tracheids were selected which showed a relative position 0.3 in the annual ring. For the late-wood tracheid model those tracheids were selected which showed a relative position 0.96 in the annual ring. In models describing the earlywood tracheid variability (Fig. 3) it was found that with the increasing distance from the stem pith transverse dimensions of a tracheid increased. The most marked increase in the tracheid dimension (radial direction) occurred in the region of juvenile wood. Maximum values were reached in the 30th

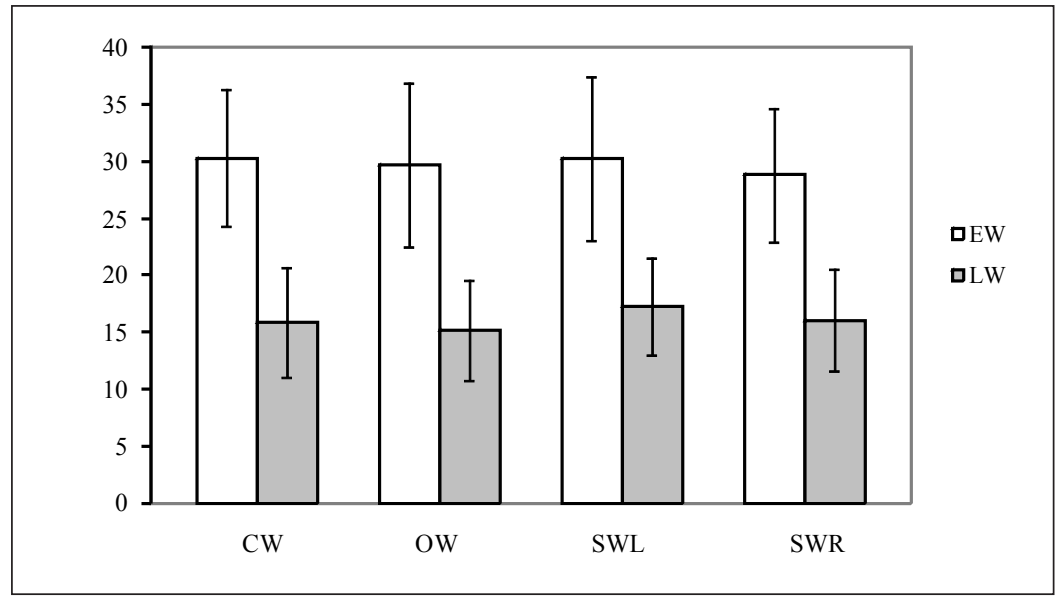

2: Box diagram - transverse dimensions of an early-wood tracheid and late-wood tracheid in $\mu m$ for particular zones (all data were used) 
I: Average radial dimension of an early-wood tracheid (EW) and late-wood tracheid ( $L W)$ in different height and zones in the stem (CW-compression woodzone, OW-opposite zone, SWL and SWR-lateral wood zones)

\begin{tabular}{cccccc}
\hline Type & $\begin{array}{c}\text { Height } \\
(\mathbf{m})\end{array}$ & CW & OW & SWL & SWR \\
\hline 22 & $25.60 \pm 0.55$ & $25.68 \pm 0.60$ & $27.95 \pm 0.53$ & $25.65 \pm 0.64$ \\
& 20 & $28.93 \pm 0.65$ & $29.35 \pm 0.76$ & $29.21 \pm 0.68$ & $29.20 \pm 0.65$ \\
& 18 & $29.35 \pm 0.82$ & $29.66 \pm 0.85$ & $31.39 \pm 0.89$ & $28.73 \pm 0.71$ \\
& 15 & $30.96 \pm 0.69$ & $30.88 \pm 0.78$ & $33.03 \pm 0.74$ & $29.27 \pm 0.71$ \\
& 12 & $30.37 \pm 0.87$ & $30.00 \pm 0.87$ & $32.33 \pm 0.79$ & $30.69 \pm 0.97$ \\
& 10 & $30.42 \pm 0.70$ & $29.78 \pm 0.85$ & $32.85 \pm 0.84$ & $28.30 \pm 0.71$ \\
& 8 & $33.16 \pm 0.69$ & $29.12 \pm 0.67$ & $37.40 \pm 1.62$ & $29.38 \pm 0.66$ \\
& 6 & $31.50 \pm 0.62$ & $31.82 \pm 0.64$ & $32.30 \pm 0.87$ & $29.04 \pm 0.63$ \\
\hline 22 & $14.36 \pm 1.03$ & $12.60 \pm 1.10$ & $13.35 \pm 0.99$ & $14.16 \pm 1.13$ \\
& 20 & $14.60 \pm 0.85$ & $14.82 \pm 1.13$ & $14.81 \pm 0.94$ & $16.95 \pm 1.34$ \\
& 18 & $14.83 \pm 1.30$ & $14.91 \pm 0.99$ & $16.69 \pm 1.01$ & $15.96 \pm 0.95$ \\
& 15 & $17.66 \pm 1.56$ & $14.75 \pm 1.14$ & $14.72 \pm 0.91$ & $15.43 \pm 1.31$ \\
& 12 & $14.13 \pm 1.06$ & $14.14 \pm 1.26$ & $14.81 \pm 0.97$ & $13.57 \pm 0.82$ \\
& 10 & $16.46 \pm 1.27$ & $16.25 \pm 1.07$ & $17.14 \pm 0.95$ & $19.92 \pm 1.79$ \\
& 8 & $17.01 \pm 1.13$ & $17.09 \pm 1.33$ & $20.13 \pm 2.15$ & $14.74 \pm 1.06$ \\
& 6 & $17.29 \pm 1.46$ & $15.09 \pm 1.13$ & $20.56 \pm 0.90$ & $16.89 \pm 1.22$ \\
\hline
\end{tabular}

II: Results of the Tukey method of the multiple comparison of the tracheid transverse dimension between particularzones $(P<0.05$ statistically significant difference, $P>0.05$ statistically insignificant difference)

\begin{tabular}{cccccc}
\hline \multicolumn{2}{c}{ Tracheid type } & \multicolumn{5}{c}{ EW } \\
\hline \multirow{4}{*}{ Zone } & CW & OW & SWL & SWR \\
\hline \multirow{3}{*}{ LW } & CW & & 0.021745 & 0.000008 & 0.000008 \\
& OW & 0.127710 & & 0.000008 & 0.000022 \\
& SWL & 0.000071 & 0.000008 & & 0.000008 \\
\hline
\end{tabular}

annual ring. In next years, the dimension stagnation occurred and in last annual rings, it was possible to observe the negligible decrease in the tracheid dimension. The result was also corroborated using ANOVA which showed that variability along the stem radius (for all zones) was a significant factor affecting the tracheid dimensions. Trends and values along the stem radius in OW, SWL and SWR zones are nearly the same. As for the stem height, an inverse trend was found - transverse dimensions of a tracheid decrease with the stem height. In the models, a limit of $12 \mathrm{~m}$ is evident. Up to the limit height, the tracheid dimensions decrease gradually, however, above the limit the dimension decrease is marked. In Tab. III, functions are given describing the variability of a tracheid in relation to its position in the tree stem. The found out models as well as particular coefficients were statistically significant.

Coefficients of determination for an EWT range between 0.382 and 0.692. These values indicate medium strong or even strong dependence of the tracheid dimension on the position in a stem. In models describing the variability of a LWT, it is possible to notice only minimum changes in the tracheid dimensions. Although models as a whole are statis- tically significant coefficients of determination for particular models are very low ranging from 0.055 to 0.164 . These low values of the coefficients give evidence of the very low effect of a position in a stem on the late-wood tracheid dimensions. Similar conclusions were derived using ANOVA which confirmed the effect of height and radius on the tracheid dimensions but, simultaneously, statistically significant effects were found only between some heights and annual rings.

In models describing variability of tracheids at particular heights (Fig. 4, models for the compression zone CW and opposite zone OW are given), changes in the tracheid radial dimensions within an annual ring are evident. Between relative positions 0 and 0.6 , it is possible to notice EWT. From the relative position 0.6 to 0.9 , a gradual decrease in tracheid dimensions occurs - the transition area between EWT and LWT. From the relative position 0.9, it is possible to observe LWT. Effects of the stem radius on the tracheid variability are similar as in previous models. At a height of 6 and $15 \mathrm{~m}$, increasing the tracheid is evident to the 30th annual ring, ie in the area of juvenile wood. In the following years, it is possible to notice a gradual decrease in the tracheid 


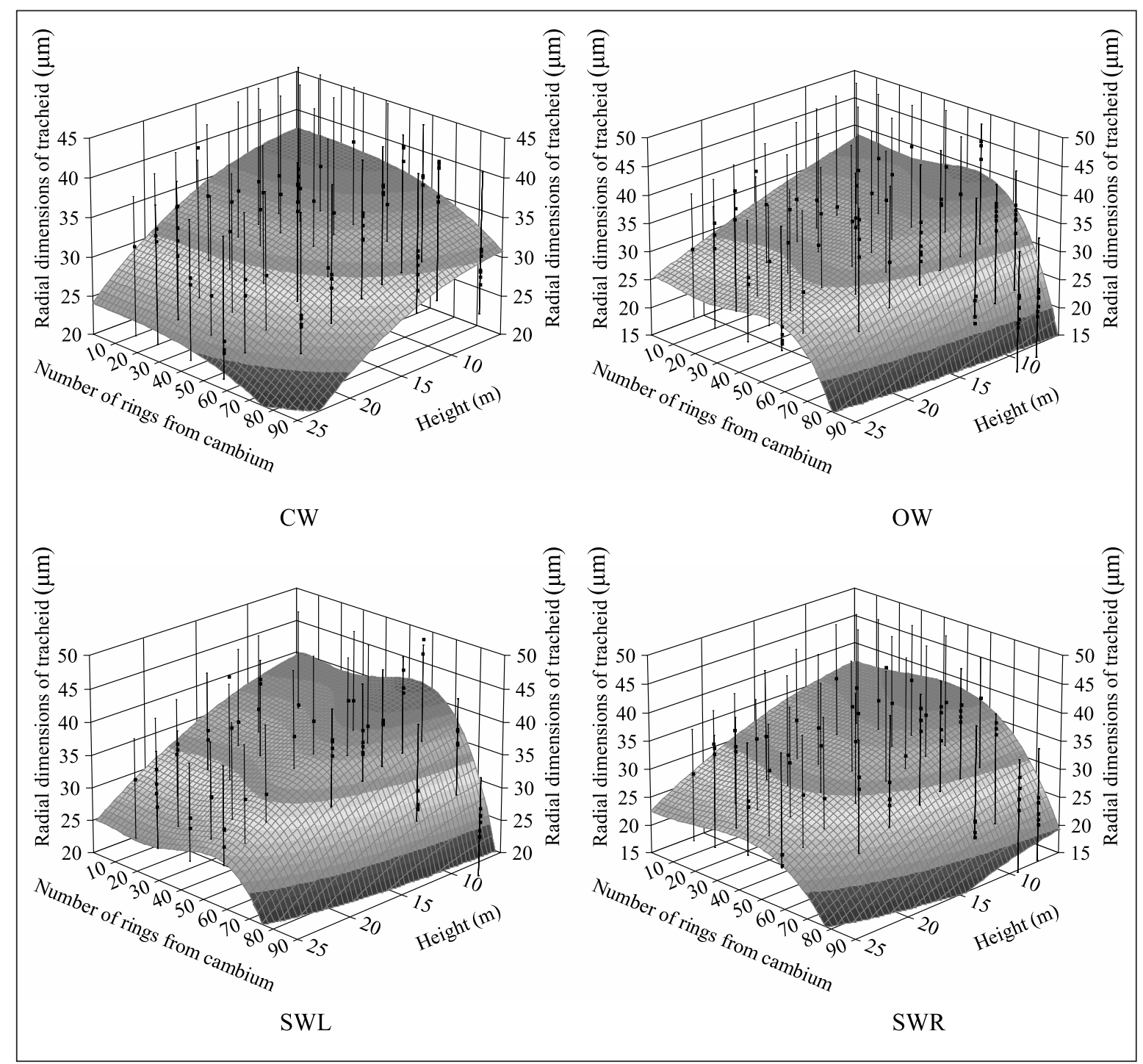

3: Radial dimensions of an early-wood tracheid - relative position in an annual ring 0.3. CW - compression wood zone, OW - opposite zone, SWL and SWR - lateral zones

III: Table of resultant functions and coefficients of determination of the selective and basic sets for the radial dimension of an early-wood (EW) and late-wood (LW) tracheid in particularzones of a stem $\left(* p<0.01,{ }^{* *} p<0.05,{ }^{* * *} p>0.05\right.$ )

\begin{tabular}{|c|c|c|c|c|c|c|c|c|c|c|}
\hline $\begin{array}{l}\text { Trach. } \\
\text { Type }\end{array}$ & Zone & Function & \multicolumn{2}{|c|}{$\mathbf{R}^{2}$} & \multicolumn{6}{|c|}{ Coefficients } \\
\hline EW & $\begin{array}{l}\text { CW } \\
\text { OW } \\
\text { SWL } \\
\text { SWR }\end{array}$ & $\begin{array}{l}\mathrm{z}=\mathrm{a}+\mathrm{bx}^{2.5}+\mathrm{cy}^{3} \\
\mathrm{z}=\mathrm{a}+\mathrm{bx} \ln \mathrm{x}+\mathrm{cy} \mathrm{y}^{2} \ln \mathrm{y}+\mathrm{dy}^{2.5}+\mathrm{ey}^{3} \\
\mathrm{z}=\mathrm{a}+\mathrm{bx}^{2}+\mathrm{cy}^{2} \ln \mathrm{y}+\mathrm{dy}^{2.5}+\mathrm{ey}^{3} \\
\mathrm{z}=\mathrm{a}+\mathrm{bx}^{2}+\mathrm{cy}^{2.5}+\mathrm{dy}^{3}\end{array}$ & $\begin{array}{l}0.398^{*} \\
0.520^{*} \\
0.692^{*} \\
0.466^{*}\end{array}$ & $\begin{array}{l}0.371^{*} \\
0.490^{*} \\
0.665^{*} \\
0.438^{*}\end{array}$ & $\begin{array}{l}37.836^{*} \\
39.709 * \\
40.638^{*} \\
37.226^{*}\end{array}$ & $\begin{array}{l}-0.00439 * \\
-0.17322^{*} \\
-0.02455^{*} \\
-0.02350^{*}\end{array}$ & $\begin{array}{l}-0.00001^{*} \\
-0.02621^{* * *} \\
-0.02672^{* *} \\
0.00098^{*}\end{array}$ & $\begin{array}{l}* \\
0.02165^{* * *} \\
0.02225^{* *} \\
-0.00013^{*}\end{array}$ & $\begin{array}{l}* \\
-0.00100^{*} \\
-0.00104^{* *} \\
*\end{array}$ & \\
\hline LW & $\begin{array}{l}\text { CW } \\
\text { OW } \\
\text { SWL } \\
\text { SWR }\end{array}$ & $\begin{array}{l}z=a+b x+c x^{2}+d y+e y^{2} \\
z=a+b x+c y+d y^{2}+e y^{3}+f y^{4} \\
z=a+b x+c \ln y \\
z=a+b y^{2.5}+c y^{3}\end{array}$ & $\begin{array}{l}0.120^{* * *} \\
0.134^{*} \\
0.055^{* * *} \\
0.164^{*}\end{array}$ & $\begin{array}{l}0.053 * * * \\
0.112^{*} \\
0.019^{* * *} \\
0.133^{*}\end{array}$ & $\begin{array}{l}11.664 * \\
12.782 * \\
14.893 * \\
10.631 *\end{array}$ & $\begin{array}{l}0.55851^{* * *} \\
-0.12862^{*} \\
-0.09726^{* *} \\
0.00036^{* *}\end{array}$ & $\begin{array}{r}-0.02634 * * * \\
0.30645^{* * *} \\
-0.32317^{* * *} \\
-0.00003^{* * *}\end{array}$ & $\begin{array}{r}0.03140^{* *} \\
-0.01695^{* *}\end{array}$ & $\begin{array}{r}-0.00071^{* *} \\
0.00033^{* *}\end{array}$ & $-0.00001^{*}$ \\
\hline
\end{tabular}

dimensions. At a height of $22 \mathrm{~m}$, values are available only to the 45th annual ring. In these models, it is possible to observe the tracheid increment throughout the stem radius. In Tab. IV, particular coefficients and coefficients of determination are given ranging between 0.55 and 0.80 . These values give evidence of the high dependence of radial dimensions of a trac- heid on the relative position in an annual ring and position within the stem radius. Models and respective coefficients were statistically significant.

Fig. 5 describing the tracheid variability in relation to the relative position in an annual ring. The diagram demonstrates that annual rings in compression wood show the high number of tracheids within 


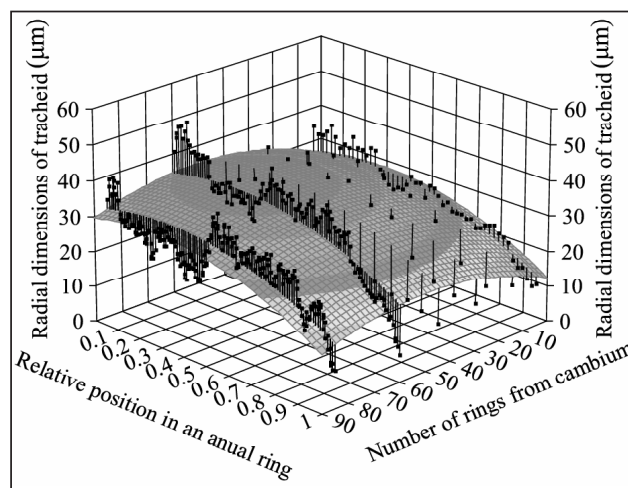

CW

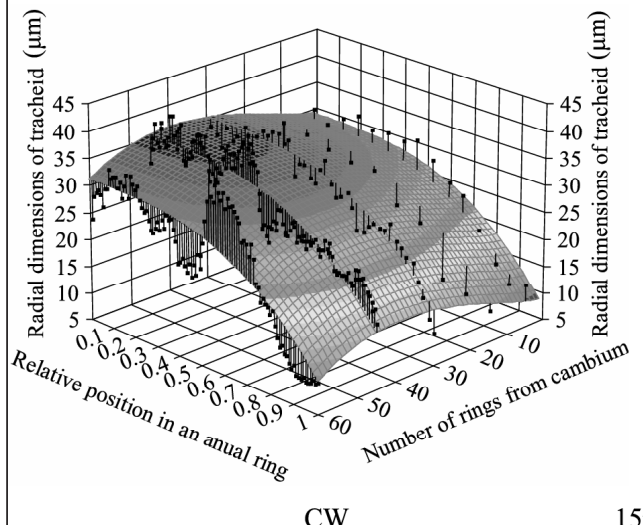

CW

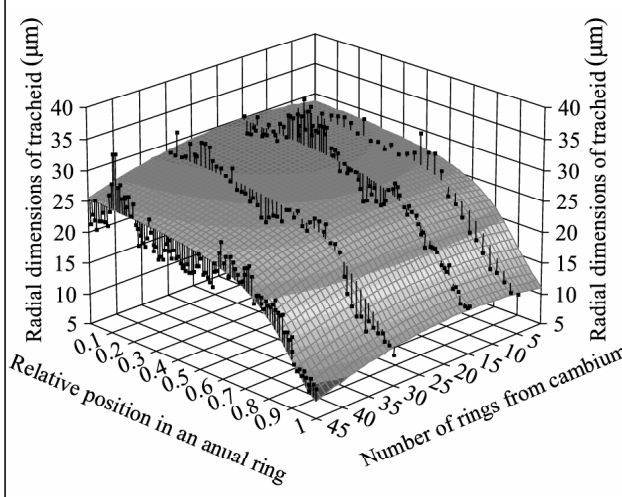

$\mathrm{CW}$

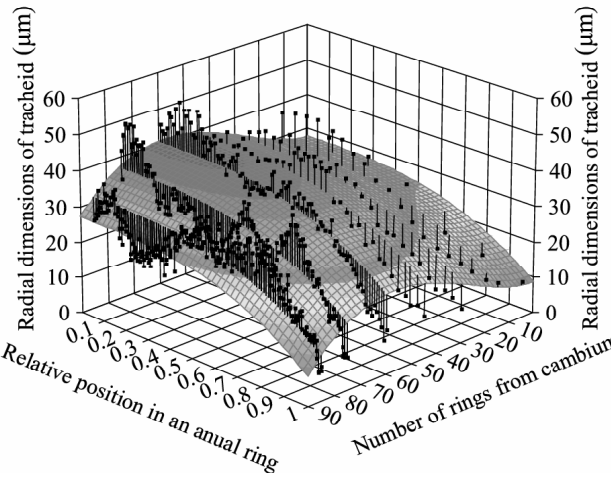

$6 \mathrm{~m}$

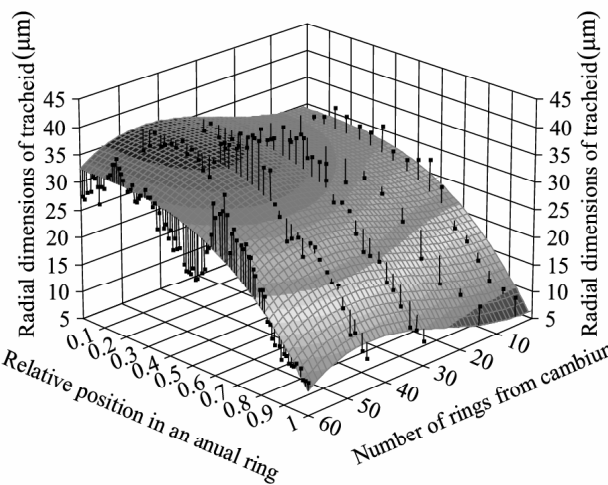

$15 \mathrm{~m}$

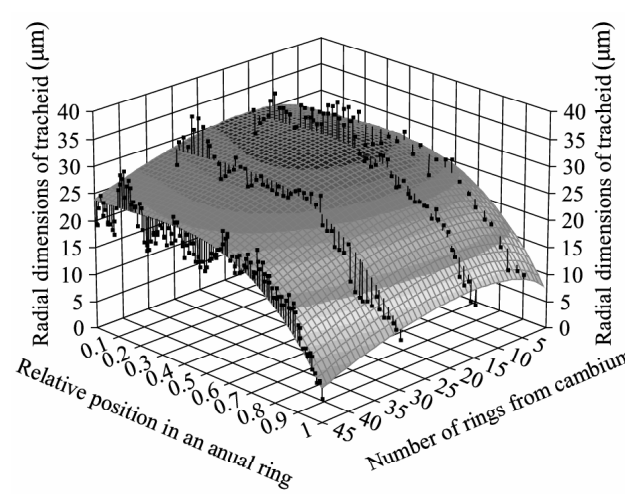

$22 \mathrm{~m}$

4: Tracheid variability at various heights (CW-compression zone, OW-opposite zone)

an annual ring as compared with an annual ring in the opposite zone (OW). Annual rings with compression wood show $1.89 \times$ more tracheids as compared with an annual ring from the opposite side. It is also possible to notice that in the compression zone, annual ring dimensions of compression tracheids in the relative position between 0.4 and 0.9 are nearly constant.

Fig. 6 describing an annual ring with compression wood. At the beginning of the growing season, cambium produced early-wood tracheids the transverse shape of which corresponded to tracheids of normal wood (tetragonal to hexagonal form). In a transitional zone, tracheids show thicker cell walls but their form is more or less $\mathrm{x}$-gonal. In the compression wood zone, tracheids show circular shape on their cross section, thick cell walls and intercellular spaces between tracheids. At the end of an annual ring, it is possible to notice LWT showing x-gonal form on their cross section and thick cell walls which are typical of LWR.

\section{DISCUSSION}

The aim of the paper was to determine variability of cross dimensions of tracheids in radial direction in relation to their position in a stem. Studies in the field of the microscopic structure of wood (transverse dimensions and length of tracheids) were car- 

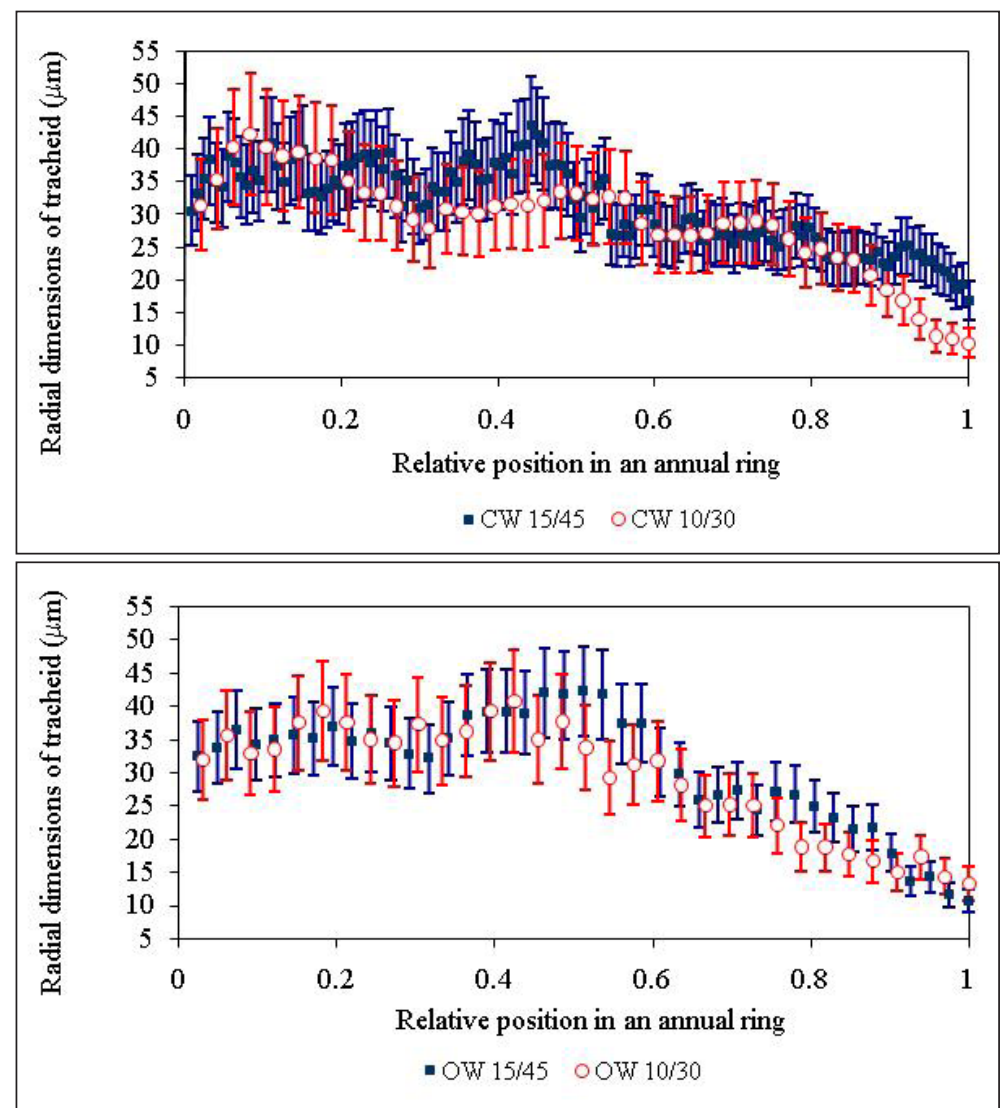

5: Comparison of tracheid dimensions in relation to the relative position in an annual ring; compression zone (CW) and opposite zone (OW), height 15 metres (annual ring 45) and 10 metres (annual ring 30)
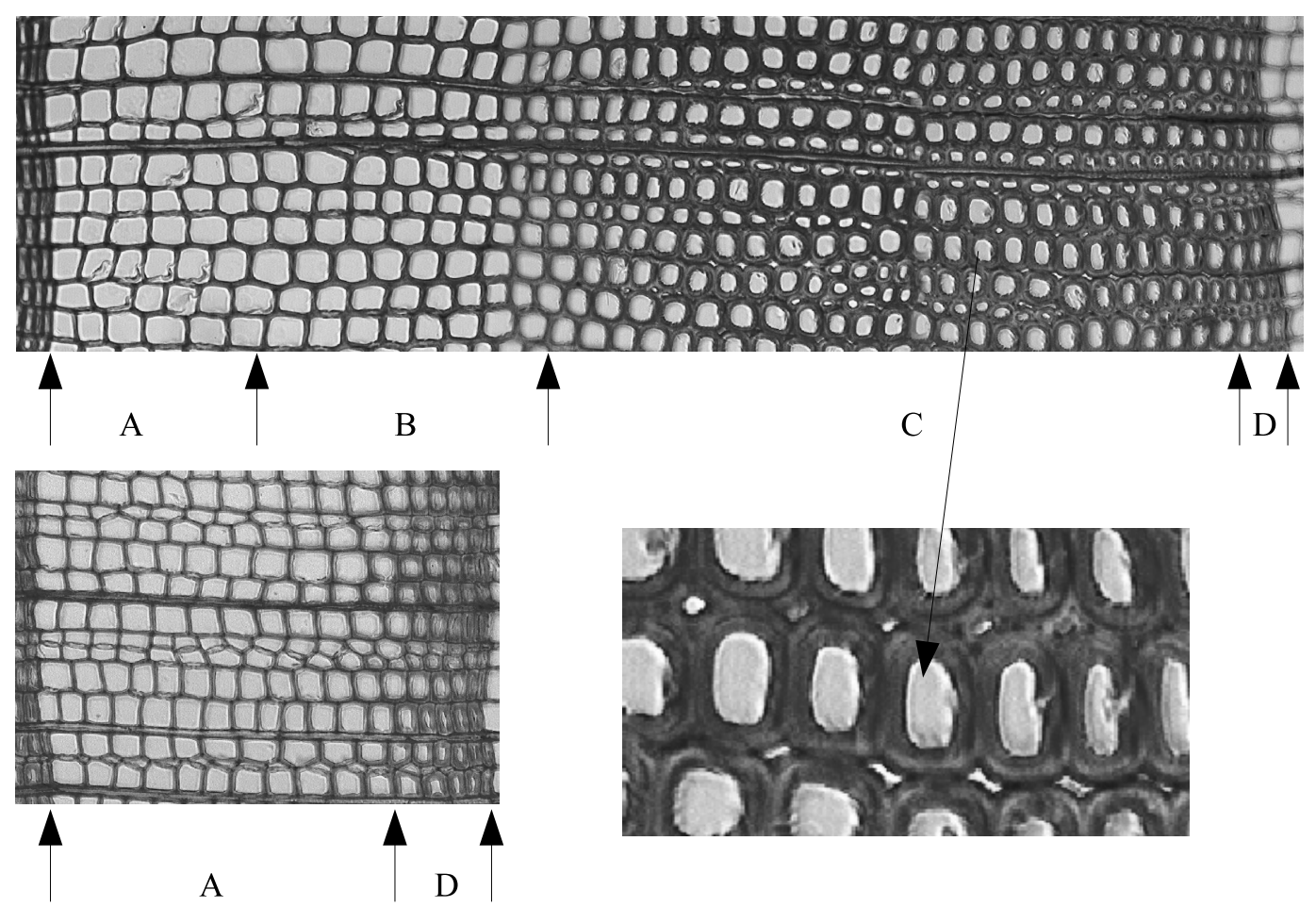

6: The microscopic photograph of an annual ring with the occurrence of compression wood from the $C W$ zone ( $A$ - early wood, $B$ - transitional wood, C - reaction compression wood, D - late wood) and with normal wood from the OW zone (A - early wood, D - late wood) 
IV: Tracheid variability at various heights - Table of resultant functions with coefficients of determination of the sampling and basic set $\left({ }^{*} p<\right.$ $0.01, * * p<0.05$ )

\begin{tabular}{|c|c|c|c|c|c|c|c|c|c|c|}
\hline \multirow{2}{*}{$\begin{array}{c}\text { Trach. } \\
\text { Type }\end{array}$} & \multirow{2}{*}{ Zone } & \multirow{2}{*}{ Function } & \multicolumn{2}{|l|}{$\mathbf{R}^{2}$} & \multicolumn{6}{|c|}{ Coefficients* } \\
\hline & & & sampling & basic & $\mathrm{a}$ & b & c & d & e & $\mathbf{f}$ \\
\hline CW & 22 & $z=a+b x+c x \ln x+d y^{2.5}+e y^{3}$ & $0.803 *$ & $0.799 *$ & $26.383 *$ & $0.8558 *$ & $-0.2323 *$ & $16.5886^{* *}$ & $-33.9418^{*}$ & \\
\hline CW & 15 & $z=a+b x \ln x+c x^{3}+d y^{3}$ & $0.710 *$ & $0.706^{*}$ & $29.505^{*}$ & 0.0807* & $-0.0001^{*}$ & $-20.2755^{*}$ & & \\
\hline CW & 6 & $z=a+b x+c x^{2}+d y+e y^{2}$ & $0.436^{*}$ & $0.429 *$ & $25.841^{*}$ & $0.3578^{*}$ & $-0.0035^{*}$ & $16.0105^{*}$ & $-29.2715^{*}$ & \\
\hline OW & 22 & $z=a+b x+c x \ln x+d y^{2}+e y^{3}$ & $0.789 *$ & $0.785^{*}$ & $24.751^{*}$ & $1.3673 *$ & $-0.3642 *$ & $20.0154 *$ & $-37.7186^{*}$ & \\
\hline OW & 15 & $z=a+b x^{2} \ln x+c x^{3}+d y^{3}$ & $0.770^{*}$ & $0.765^{*}$ & $29.710^{*}$ & $0.0038^{*}$ & $-0.0002 *$ & $-23.0645^{*}$ & & \\
\hline OW & 6 & $\mathrm{z}=\mathrm{a}+\mathrm{bx^{2 }}+\mathrm{cx}^{2.5}+d \mathrm{y}^{3}$ & $0.553 *$ & $0.550^{*}$ & $27.663^{*}$ & $0.0200^{*}$ & $-0.0021^{*}$ & $-18.9203 *$ & & \\
\hline SWL & 22 & $\mathrm{z}=\mathrm{a}+\mathrm{bx}^{2.5}+\mathrm{cx}^{3}+d \mathrm{y}^{3}$ & $0.766^{*}$ & $0.763 *$ & $33.514 *$ & $-0.0032 *$ & $0.0004 *$ & $-18.7716^{*}$ & & \\
\hline SWL & 15 & $z=a+b x+c x^{2}+d x^{3}+e y+f y^{2}$ & $0.682 *$ & $0.675^{*}$ & $21.426^{*}$ & 1.4910* & $-0.0490 *$ & $0.0004 *$ & $38.2676^{*}$ & $-58.5827^{*}$ \\
\hline SWL & 6 & $\mathrm{z}=\mathrm{a}+\mathrm{bx} \ln \mathrm{x}+\mathrm{cx}^{3}+\mathrm{dy}^{3}+\mathrm{ey}^{0.5} \ln \mathrm{y}$ & $0.563 *$ & $0.559 *$ & $34.276^{*}$ & $0.0912 *$ & $0.0000^{*}$ & $-28.3307^{*}$ & $11.5697 *$ & \\
\hline SWP & 22 & $\mathrm{z}=\mathrm{a}+\mathrm{bx}^{2}+\mathrm{cx}^{2.5}+d \mathrm{x}^{3}+\mathrm{ey}^{3}$ & $0.753 *$ & $0.748 *$ & $26.282 *$ & $0.1487 *$ & $-0.0470 *$ & $0.0037 *$ & $-16.7724 *$ & \\
\hline SWP & 15 & $\mathrm{z}=\mathrm{a}+\mathrm{bx^{2 }}+\mathrm{cx}^{3}+\mathrm{dy}^{2}+\mathrm{ey}^{2.5}+\mathrm{fy}^{3}$ & $0.651 *$ & $0.640^{*}$ & $31.678^{*}$ & $0.0114 *$ & $-0.0002 *$ & $-312.4226^{*}$ & $712.6028^{*}$ & $-424.0855 *$ \\
\hline SWP & 6 & $\mathrm{z}=\mathrm{a}+\mathrm{bx} \mathrm{x}^{2.5}+\mathrm{cx^{3 }}+\mathrm{dy^{1.5 }}+\mathrm{ey}^{2}+\mathrm{fy}^{2.5}$ & $0.553 *$ & $0.546 *$ & $31.005 *$ & $0.0014 *$ & $-0.0002 *$ & $-194.3696^{*}$ & 481.8800* & $-308.8887 *$ \\
\hline
\end{tabular}

ried out as early as the end of the 19th century being also carried out at the present time. Based on the studies it is evident that variability of tracheids is considerable. Transverse dimensions of tracheids are affected by the kind of wood, site and climatic conditions, position within the stem radius and height and position in an annual ring (Horáček, 2003; Gryc and Horáček, 2003; Sarén et al., 2001; Panshin and Zeeuw, 1980; Diaz-Váz et al., 1975; Trendelenburg, 1939).

The average dimension of an early-wood tracheid in radial direction ranged about $30 \mu \mathrm{m}$ in particular zones. The late-wood tracheid dimension in radial direction in particular zones of a stem reached a value of about $16 \mu \mathrm{m}$. Thus, the values occurred in a range which is given for coniferous wood tracheids by other authors (Horáček, 2004; Gryc and Horáček, 2003; Fengel and Stoll, 1977; Onaka, 1949; Trendelenburg, 1939).

Based on determined dimensions, models were constructed describing the tracheid variability in relation to its position in a stem (Fig. 5). In the first type of models where tracheids were used showing the relative position in an annual ring 0.3 (earlywood tracheids), it appeared that transverse dimensions of tracheids in the area of juvenile wood significantly increased with the increasing distance from the stem pith. Maximum values were reached in the 30th annual ring, in the following years stagnation occurred or decrease in the tracheid dimensions. A trend in increasing the tracheid dimensions in the area of juvenile wood was corroborated by models at particular heights. The determined trends correspond to literature sources (Gryc and Horáček, 2003; Sarén et al., 2001). A decrease in the tracheid transverse dimensions in radial direction along the stem height can be explained by the increasing proportion of juvenile wood from the total area of the stem disc.In models depicting changes in the tracheid dimensions in relation to its position in an annual ring and stem radius (Fig. 6), it is evident that tracheid dimensions decrease from spring wood to late wood. These changes are related to the tracheid differentiation. At the end of the growing season, late-wood tracheids remain longer in the maturing area while in the area of radial increasing, they remain for a shorter period (Horáček, 2003). Along the stem radius, increase in the tracheid dimensions occurred in the area of juvenile wood, subsequently a maximum was achieved and in the next years, stagnation occurred or decrease in the tracheid dimensions (Gryc and Horáček, 2003).

Annual rings with compression wood demonstrated the following structure: spring wood, compression wood - transition stage, compression wood and last tracheids were of the same shape as latewood tracheids. This structure of an annual ring was noticed in all annual rings under investigation which showed compression wood. An annual ring structured in this way as one of the possibilities of the occurrence of compression wood within an annual ring is also given by Timell (1986). Early wood was formed by wide tracheids with a wide lumen and thin cell walls which is typical of early-wood tracheids functioning as conductive elements as compared with late-wood tracheids which showed a small diameter in radial direction, narrow lumen and thick cell walls typical of tissues with mechanical functions (Wagenführ, 1999; Trendelenburg, 1932).

Tracheids of compression wood showed circular shape, thick cell wall and intercellular spaces between tracheids. The structure of compression wood corresponds to conclusions published so far (Wagenführ, 1999; Mauer and Fengel, 1991; Timell, 1986; Casperson and Zinßer, 1965; Casperson, 1962; Knige, 1958; Rak, 1957; Trendelenburg, 1932). In comparing the number of tracheids in an annual ring in a compression zone and opposite zone annual rings with compression wood show nearly the double number of tracheids. This result is caused by wider annual rings in the compression zone. 


\section{SUMMARY}

The paper was aimed at the determination of variability of tracheid dimensions in spruce wood in relation to their position in a stem. Significant changes of tracheids were found along the height and radius of a stem. There were statistically significant differences between particular annual rings (variability along the stem radius). The height of a stem was also statistically significant.

On the basis of the results obtained 3D models were created (for zones CW, OW, SWL, SWP; models for an early-wood tracheid and late-wood tracheid) depicting changes in transverse dimensions of the spruce tracheid in relation to its position in a stem. In the models, decrease in tracheid dimensions occurs at upper heights of a stem. On the other hand, radial dimensions of tracheids increase with the increasing distances from the stem pith reaching their maximum in the 30th annual ring. In the following years, they show stagnation or decrease in the tracheid dimensions.

The importance of the paper consists in the enlargement of knowledge on the structure of spruce wood. At the same time, the paper can contribute to the partial explanation of the different behaviour of physical and mechanical properties of wood in particular parts of a stem.

\section{SOUHRN}

Vliv polohy ve kmeni na variabilitu radiálního rozměru tracheidy smrku (Picea abies /L./ Karst.) s př́tomností reakčního dřeva

Cílem práce bylo popsat variabilitu rozměru tracheidy u smrku v závislosti na poloze v kmeni. Statisticky významné změny v radiálním rozměru tracheidy byly nalezeny nejen po poloměru, ale i po výšce kmene. Z naměřených hodnot byly vytvořeny 3D modely (pro zóny CW, OW, SWL a SWR), které popisují změnu radiálního rozměru jarních a i letních tracheid v závislosti na poloze v kmeni. Z modelů vyplývá, že rozměr tracheid se snižuje s výškou kmene, zatímco po poloměru kmene se radiální rozměr tracheidy zvyšuje. Nejvyšší přírůstek radiálního rozměru tracheidy byl pozorován mezi dření a 30. letokruhem, v následujících letech je rozměr konstantní, popř. mírně klesající. Dále byla studována struktura letokruhů s př́ítomností reakčního (tlakového) dřeva. Bylo zjištěno, že letokruhy s tlakovým dřevem mají výrazně modifikovanou strukturu v porovnání s dřevem normálním, popř. letokruhem z protilehlé části kmene. V letokruhu s př́tomností tlakového dřeva byly pozorovány jarní, přechodové, tlakové a letní tracheidy. Tlakové tracheidy se vyznačovaly kruhovým tvarem, silnou buněčnou stěnou a přítomností mezibuněčných prostor.

smrk, radiální rozměr tracheidy, tlakové dřevo

Acknowledgment

Supported by the Ministry of Education, Youth and Sport of the Czech Republic, Project. No. MSM 6215648902.

\section{REFERENCES}

BÖTSCHE, H., KÜHN, K., 1988: Bildung und Eigenschaften des Holzes von Fichten (Picea abies /L./ Karst.) aus Waldschadengebieten. Hamburk, Mitteilungen der Bundesforschungsalt für Forst und Holzwirtschaft: 188.

DENNE, M. P., 1973: Tracheid Dimensions in Relation to Shoot Vigour in Picea. Forestry: 117-124.

DEWITZ, G. S., 1969: Variation der Strukturelemente im Nadelholz. Holztechnologie, 10: 185-189.

DIAZ-VÁZ, J. E., ECHOLS, R., KNIEGGE, W., 1975: Vergleichende Untersuchung der Schwankungen von Tracheidendimension und röntgenoptisch ermittelter Rohdichte innerhalb des Jahrringes. Forstwissenschaft Cbl.: 161-175.

CASPERSON, G., 1962: Über die Bildung der Zellwand beim Reaktionsholz. Holztechnologie, 16: 217-223.
CASPERSON, G., ZINSSER, A., 1965: Zur Spaltenbilding im Druckholz von Pinus sylvestris L. Holz als Roh-und Werkstoff, 23: 49-55.

FENGEL, D., STOLL, M., 1973: Über die Veränderung des Zellquerschnitts, der Dicke der Zellwand und der Wandschichten von Fichtenholz - Tracheiden innerhalb eines Jahrringes. Holzforschung, 27: 1-7.

GRYC, V., HORÁČEK, P., 2003: Vliv polohy ve kmeni na morfologii tracheid u smrku (Picea abies /L./ Karst.). MENDELNET 2003: Konference doktorandů LDF MZLU v Brně, Brno: 53-58.

GRYC, V., HORÁČEK, P., 2004: Influence of Forestry Practices on Wood - Preview. MENDELNET 2004. Konference doktorandi̊ LDF MZLU v Brně, Brno: 45-50.

HORÁČEK, P., 2003: Wood structure: a tool for evaluating in growing conditions of Norway spruce. Ekológia (Bratislava), 23: 147-162. 
KNIGGE, W., 1958: Das Phänomen der Reaktionsholzbildung und seine Bedeutung für die Holzverwendung. Forstarchiv, 29: 4-10.

KOLLMAN, F., 1951: Technologie des Holzes und der Holzwerkstoffe. Berlin, Springer Verlag: 1050.

KUČERA, B., 1973: Holzfehler und ihr Einfluß auf die mechanischen Eigenschaften der Fichte und Kiefer. Holztechnologie, 14: 8-17.

MAUER A., FENGEL D., 1991: Elektromikroskopische Darstellung von strukturellen Einzelheiten in Nadelholz-Zellwänden anhand sehr dünner Ultramikrotomschnitte. Holzals Roh-und Werkstoff, 49: 53-56.

MATOVIČ, A., GANDELOVÁ, L., 1980: Charakteristika dřeva smrku. Sborník mezinárodní vědecké konference. VŠZ v Brně. Lesnická fakulta. Brno: 85-90.

MITSCHELL, M. D., DENNE, M. P., 1997: Variation of Picea sitchensis in relation to within-tree trends in tracheid diameter and wall thickness. Forestry, 70: 47-60.

ONAKA, F., 1949: Studies on compression and tension wood. Mokuzai Kenkyo Wood Res. Institut. Kyoto: 88.

PANSHIN, A. J., DE ZEEUW, C., 1980: Textbook of wood technology. New York, McGraw-Hill, Inc.: 722.
PLOMION, CH., LEPROVOST, G., STOKES, A., 2001: Wood Formation in Trees. Plant Physiology, 127: 1513-1523.

RAK, J., 1957: Fysikální vlastnosti reakčního dřeva smrku. Drevárský výskum, 1:27-52.

SARÉN, M., SERIMAA, R., ANDERSSON, S., PAAKKARI, T., SARANPÄÄ, P., PESONEN, E., 2001: Structural Variation of Tracheids in Norway Spruce (Picea abies [L.] Karst.). Journal of Structural Biology: 101-109.

TIMELL, T. E., 1986: Compression Wood in Gymnospermes. Berlin, Springer Verlag: 705.

TRENDELENBURG, R., 1939: Das Holz als Rohstoff. München-Berlin, Lehmanns Verlag: 435.

TRENDELENBURG, R., 1932: Über die Eigenchaften des Rot- oder Druckholz der Nadelhölzer. Algemeine Forst und Jagd Zeitung, 1: 1-14.

VAVRČÍK, H., GRYC, V., 2004: Metodika výroby mikroskopických preparátů ze vzorků dřev, Acta Universitatis agriculturae et silviculturae Mendelianae Brunensis, LII: 169-176.

WAGENFÜFR, R., 1999: Anatomie des Holzes, Strukturanalytik - Identifizierung - Nomenklatur - Mikrotechnologie. Leipzig, DRW - Verlag: 707. 